\title{
Rafael Maya o la Pasión Estética
}

VA un trecho de La vida en la sombra, pasando por Domus autea a Los cotos del mediodía. El poeta se transforma sin cambiar en lo substancial los caracteres de su visión artística de la vida. Se transforma en beneficio de la poesía y queda, sin embargo, igual a sí mismo, porque la transformación es orgánica. Hemos visto en América poderosos maestros de la dicción poética en el empeño de transformarse voluntariamente, y los hemos visto disminuir en fuerza hasta reducirse a las tres dimensiones del sólido ordinario. Cambiar, de acuerdo con un deseo de parecerse a otros, es abdicar de la personalidad, la más triste y peor figurada de las abdicaciones. Nuestro yo varía continuamente en las alternativas del estudio, de la experiencia, del conflicto vital, pero variarle, como el tocado de las mujeres o como la apariencia de los escaparates en un almacén de novedades, es un pecado contra el espíritu santo.

Va un trecho del D'Annunzio que escribió "Il dolce grappolo" en Isotteo y la Quimera, al poeta de "Las Manos", en el macrocosmos de Las Laudes, pero del principio al fin de su carrera, pasando por las Elegias romanas, es uno mismo el artífice de su propia vida, el joyero de la frase, el hombre que se mira en el universo, consciente de que el universo se mira en él. Una transformación semejante se opera en el fondo y en la forma de Rafael Maya. La modificación guarda armonía con su vida, con su temperamento, y es tan suave y tan íntima, que acaso él mismo no la perciba. Tampoco saben las flores cuáles son los movimientos de origen subterráneo que llegan hasta el cáliz y los pétalos para hacerlos abrirse y ostentar toda la riqueza de sus formas y colores. $\mathrm{Ni}$ puede tampoco el hortelano seguir paciente y minuciosa- 
mente los pequeños movimientos que hace el botón de rosa para desdoblarse en la fastuosidad de una flor. Una tarde la planta está cubierta de promesas verdes, y a la mañana siguiente el aire cargado de perfumes les señala a los ojos una orgía de colores que empezó en la obscuriđad y se prolonga en competencia con la abundancia luminosa del claro día.

No se entienda, sin embargo, que las primeras poesías de Rafael Maya eran apenas el botón, la promesa de una inteligencia. Su naturaleza de artista floreció de repente en manifestaciones de una belleza singular y completa. Sin duda precedió a esa generosa floración primera un trabajo de gestación espiritual semejante al que transforma unos en otros los metales en las grandes presiones, en las temperaturas fabulosas, en los oscuros y ciclópeos crisoles de la profundidad planetaria.

La vida en la sombra es el espíritu disuelto en la naturaleza. No parece sino que las palabras todas del idioma, sus sonoridades, la concordancia misteriosa entre el sonido y el concepto hubieran sido inventados para que esta mente privilegiada se sirviese de ellos y nos dijese: "iMirad, la naturaleza es el verbo!"

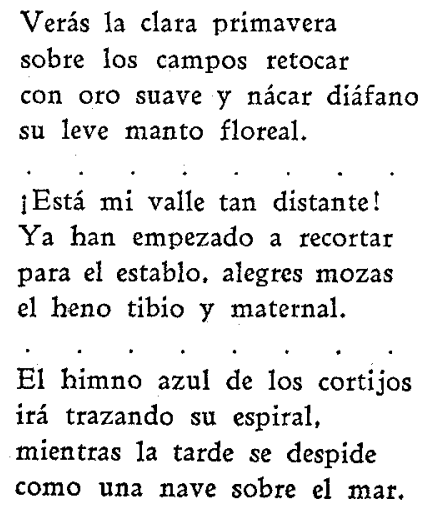

Los colores, las líneas, las sensaciones de calor y de tacto armonizan con el ritmo inquietante del eneasilabo, cuyos acentos variables le dan al pensamiento una fugacidad de hechizo.

Nó me olvides, le dice a una estrella,

Cuando entres por la rota ventana del hogar a posarte en la lámpara que no quiere alumbrar, 
o te pierdas en los caminos de un cuento

que se enreda en la tibia quietud del aposento.

La frescura de las imágenes rivaliza con la sencillez inasequible de la expresión. Poniendo atento el oído a las confesiones de esta alma de niño y de poeta profundo, sorprende el crítico a veces rincones encantados de su habitación espiritual. Una mujer le dice que no gusta de sus versos, y súbitamente le ocurren al poeta decenas de motivos por los cuales esa gentil persona no podrá nunca poner su complacencia en estas criaturas hechas de rima $y$ de sentimiento:

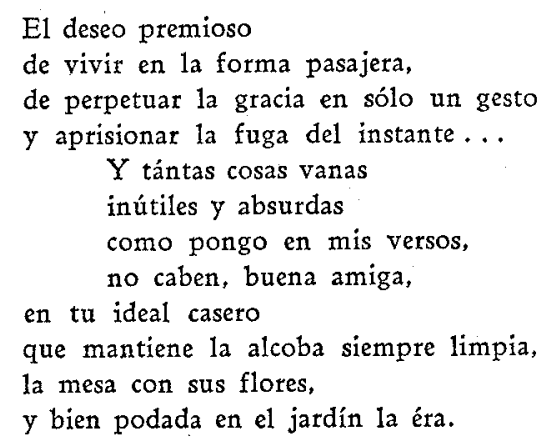

"Vivir en la forma pasajera" y "querer perpetuar la gracia en un solo gesto", son dos preceptos en los cuales se podría concentrar toda la retórica de Rafael Maya y todas las reglas de la poesía lírica. El ha "violado las arcas del tesoro que guarda la noche", y por haber acariciado con sus manos esa muchedumbre de joyas $y$ haber sentido en el oído espiritual el choque del diamante con el metal precioso, ha experimentado una sensación de plenitud.

La nota más delicada la da en los versos de Maya una melancólica incertidumbre. Ha sentido la tristeza de haber conocido. En el conocer hay un goce indefinible, pero cuando esa dulzura de la percepción se pierde en las brumas de la memoria, sobreviene en las almas delicadas un estado semejante a la melancolía. Es triste "la sombra que proyectan los objetos cuando cae sobre ellos la luz del conocimiento". Maya es demasiado consciente para gozar $\sin$ asomos de tristeza del espectáculo vital. 
La muerte agita alrededor del poeta la cuchilla de su guadaña, y él parece haber oído el ruido penetrante que hace la hoja de acero cortando el aire denso y frío de la noche. Percibe, sin duda, el ruido levísimo de las arenas en el reloj del tiempo y le despierta en la noche el rumor de la vena líquida con que se mide en la clepsidra el paso indiferente, el ademán burlesco o las muecas inclementes de las horas:

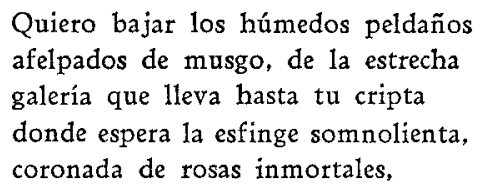

le dice a la muerte.

Aun la visión macabra es elegante y cautivadora en este poeta, dueño en todo momento de la palabra adecuada a la noción fugitiva. Y por esa noble actitud de resignación sin desafío y de altiva aceptación del absurdo, sus poemas de muerte, sus frecuentes alusiones al olvido y la nada dejan en las mentes sanas una impresión de salud y fortaleza. La muerte en la filosofía de Maya, cuyo nombre viene a tener valor simbólico, en esta esfera del pensamiento, no es otra cosa que una de las formas de la vida.

En la riqueza de imágenes, característica de este insuperable analista de sus propias sensaciones, no es posible decir cuáles acuden a su pluma con más abundancia ni en cuáles se complace y se detiene con mayor delectación su mente de poeta. La vista, el oído, el tacto, el olfato acuden gustosos a su conjuro:

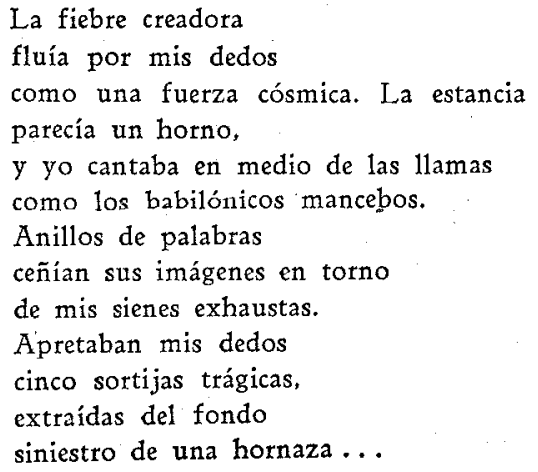


Todas las sensaciones se dan cita en esta página de poeta alucinado para comunicar la sensación del vértigo, y el desempeño es de una hechura tan digna, que ni una sola vez en la tensión exigida por el tema decae el ritmo, flaquea la imagen, o se oscurece el concepto.

Con los años Maya se liberta de la rima. Acaso la fácil armonía de las sílabas finales se le antoja ya demasiado evidente, demasiado exterior, para hacerla concordar con la estupenda riqueza de la vida interior. En Coros del mediodía escasean los consonantes y aun los asonantes. El verso libre, de una libertad indómita dentro de las exigencias de un ritmo perfecto, desarrolla frases enteras como una sola palabra, por sobre las cuales pasa el hada armonía como era llevado el espíritu creador sobre las aguas en el principio del mundo. Se ha apasionado, como D'Annunzio, del heptasílabo, ágil, fluído, noble y sencillo, capaz de adecuarse a todas las sensaciones, ayudado por instantes del noble endecasílabo. En "La muerte del héroe" ha ensayado victoriosamente una lucha con el asonante uniforme en todos los finales de verso de siete sílabas:

\footnotetext{
De súbito un flechazo vibró, y el fino dardo hincóse en su costado mientras un hilo cálido descendía a lo largo del cuerpo inmaculado.
}

El sabio dominio del idioma, del ritmo y de la imagen le sacan vencedor en estas lides, que parecen veleidades de amante apasionado.

Y este poeta que juega con las rimas, se deshace de ellas, tira por lo alto las medidas, como el juglar los platos de porcelana, vurelve a recogerlas y las dispone como los preceptos ordenan; es, además, un prosista de excelsas dotes, un narrador y cronista de los sucesos pasajeros, en cuyas manos la frase se desliza con suavi- 
dades de raso y coloraciones de paisaje lacustre en las horas de la tarde. Su prosa vale como su verso. Su manera de ver la vida, y su noción del arte hacen de él un poeta superior, cualquiera que sea la forma de expresión en que ponga sus preferencias. 